\title{
Female Students at Universities in Baden- Württemberg, Rhône-Alpes and Catalonia ${ }^{1}$ A Secondary Analysis of Gender, Interest in Science and Research, and the Intention to do a Doctorate
}

\section{Bettina Grimmer Tobias Röhl}

University of Konstanz. Department of History and Sociology bettina.grimmer@uni-konstanz.de tobias.roehl@uni-konstanz.de

\begin{abstract}
The article exhibits several differences between female and male students in BadenWürttemberg (Germany), Catalonia (Spain) and Rhônes-Alpes (France). Women often give intrinsic motivations in choosing their subjects, men on the other hand tend to be driven by extrinsic motivations. Moreover, women state more often than men that they face problems in their studies. Finally, although female students intend to do a PhD as often as male students, men still constitute the majority among PhD students. By applying several statistical tests we can show that the relatively low number of women doing a $\mathrm{PhD}$ cannot be attributed to a lack of interest in science and research among female students. While this interest has a positive effect on the intention to do a $\mathrm{PhD}$, it does not differ by gender but by subject.
\end{abstract}

Key words: sociology of education, higher education, students, gender, intention to do a $\mathrm{PhD}$, interest in science and research.

Resum. Les estudiants a les universitats de Baden-Württemberg, Rhône-Alpes i Catalunya. Una anàlisi secundària de gènere de l'interès per la ciència i la recerca i de la intenció de fer un doctorat

L'article exposa unes quantes diferències entre els estudiants femenins i masculins a BadenWürttemberg (Alemanya), Catalunya (Espanya) i Rhône-Alpes (França). Sovint, les dones tendeixen a conduir-se per motivacions intrínseques en el moment d'escollir el tipus d'estudis, mentre que els homes ho fan més aviat per motivacions extrínseques. A més, les dones declaren que han d'afrontar més problemes en els seus estudis que no pas els homes. Finalment, tot i que les estudiants tenen la mateixa intenció de fer un doctorat tan sovint com els estudiants masculins, aquests encara constitueixen la majoria d'estudiants de doctorat. Aplicant diferents proves estadístiques, es pot demostrar que el nombre relativament baix de dones que fan un doctorat no es pot atribuir a una manca d'interès per la ciència

1. This article is based on a presentation given by Bettina Grimmer at a conference of FREREF at the Villa Vigoni in May 2004. The written report of that presentation can be found in the documentation of that conference (Grimmer, 2004). We would like to thank Tino Bargel and Willi Nagl for their support and assistance. 
i la recerca entre els estudiants femenins. Mentre que aquest interès té un efecte positiu sobre la intenció de fer un doctorat, no es diferencia pel gènere sinó pel tema.

Paraules clau: sociologia de l'educació, ensenyament superior, estudiants, gènere, intenció de fer un doctorat, interès per la ciència i la recerca.

\section{Summary}

1. Introduction

2. Data

3. General results

4. Gender, interest in science and research, and the intention to do a doctorate
5. Conclusion and Outlook

6. Appendix

References

\section{Introduction}

In the last decades research on gender has become an important issue in several areas of sociology. One important theorem of most feministic theories is the assumption of «male dominated» society. Most Western societies are organised by masculine rules, values and rituals, and women take this domination for granted without thinking critically about it in their everyday lives. This is what Bourdieu called the "paradoxe de la doxa" (cf. Bourdieu, 1998).

Our analysis belongs to the area of sociology of higher education, and if we consider Bourdieu's assumption of the masculine domination we have to research the situation of women at universities, which is in that sense also a «masculine institution» (cf. "Die männliche Prägung der Universität», Peisert, 1967). The data we use is taken from a student survey that has been conducted in three European regions: Baden-Württemberg, Rhône-Alpes and Catalonia. It is our aim to treat these three areas separately and compare them.

The first part of this article deals with a descriptive presentation of gender inequalities on the undergraduate level. First of all, we observe the quantitative aspect: Given the fact that female students are no longer a minority at universities, what are the proportions of women if one considers different subjects? The next question concerns the qualitative aspect: What were the motivation for the choice of subject for both genders and what are the differences? Furthermore, we have a look at the study situation of women: What about their integration and their contacts, and do they have more problems than men during their studies? The last issue focuses on the intentions of female students to do a doctoral thesis.

The second part of this article observes the next level of the academic ladder, and tries to answer the question why women do not do a doctorate as often as men. To explain this discrepancy there are two approaches in feministic theory. The first one tries to find an explanation in the attitudes and beliefs of women themselves; the second one holds university and its struc- 
tures responsible for the lower number of women. Our sample only enables us to follow the first approach and observe individual aspects on the level of students. Hence, we try to find out if female students have a lower interest in science and research and are thus less likely to do a $\mathrm{PhD}$ than males. To answer this question we apply interferential statistics.

\section{Data}

In the context of FREREF ( «Fondation des Régions Européennes pour la Recherche en Éducation et Formation»), the three regions of BadenWürttemberg (Tino Bargel, Konstanz), Rhône-Alpes (Charles Hadji, Grenoble) and Catalonia (Josep Masjuan, Barcelona) organised a survey to observe similarities and differences between the situation of the students in those three regions.

In Baden-Württemberg, the data is part of the German student survey realised in winter semester 2000/2001. This postal self-administered questionnaire was sent to undergraduate students of all semesters. The region is represented by the two universities of Karlsruhe and Freiburg. The sample consists of 984 students. In Rhône-Alpes and Catalonia, data was collected in spring 2002. In these regions the questionnaires were given to students in their courses. These samples consist solely of third year students because they are more experienced in their studies. The presence of students of all subject groups is controlled by different subject quotas. In Rhône-Alpes the sample consists of the three universities of Grenoble, the three universities of Lyon and the universities of St. Etienne and Savoie. In Catalonia, it is mainly represented by the universities of Barcelona and Lleida. The Catalonian sample consists of 1,823 students, whereas the one of Rhône-Alpes includes 1,230 students (see for further information about the sample Bargel, Hadji and Masjuan, 2003: IIf).

\section{General results}

\subsection{Percentage of women in different subjects}

In the last 30 years, the number of female students in higher education has increased significantly. About $50 \%$ of students in all three regions considered here are women (see table 1). In Rhône-Alpes and Catalonia, the proportion of female students is even slightly above $50 \%$. However, there are significant differences in the distribution of gender not only in terms of subject studied, but also in terms of motivations and attitudes before and during the studies.

In Baden-Württemberg, the overall proportion of women in all subjects is smaller than that of men (42\%), in Rhône-Alpes and Catalonia, it is above that level (62\% and 61\%). However, the access of female and male students to different subjects varies considerably. In all of the three regions women 
Table 1. Proportions of women in the subjects among the respondents in the three regions (in per cent).

\begin{tabular}{lccc}
\hline Subjects & $\begin{array}{c}\text { Baden-Württemberg } \\
(\mathbf{9 8 1})\end{array}$ & $\begin{array}{c}\text { Rhône-Alpes } \\
(\mathbf{1 . 2 0 9 )}\end{array}$ & $\begin{array}{c}\text { Catalonia } \\
(\mathbf{1 . 7 9 1 )}\end{array}$ \\
\hline Humanities, languages & 67 & 85 & 72 \\
- History & 46 & 69 & 58 \\
- Languages & 79 & 91 & 82 \\
\hline Social sciences & 67 & 85 & 79 \\
- Psychology/pedagogy & 85 & 88 & 91 \\
- Political sc./sociology & 43 & 71 & 66 \\
\hline Law & 49 & 75 & 78 \\
\hline Economics & 34 & 46 & 55 \\
\hline Medicine & 61 & 76 & 77 \\
\hline Natural sciences & 34 & 54 & 53 \\
- Mathematics & 38 & 69 & 61 \\
- Information engineering & 13 & 33 & 15 \\
- Physics/chemistry & 27 & 50 & 54 \\
- Biology & 55 & 68 & 84 \\
\hline Engineering & 14 & 9 & 21 \\
\hline Total & 42 & 62 & 61 \\
\hline
\end{tabular}

Source: FREREF Student Survey 2000-2002, Barcelona/Grenoble/Konstanz.

dominate the humanities and languages; this effect is especially strong in Rhône-Alpes. A similar pattern is observable in the social sciences and in medicine. While in Baden-Württemberg the number of women studying law equals that of male law students, there are once again more women than men in Rhône-Alpes and Catalonia. In the subject of economics the BadenWürttembergian women are in the minority (34\%), whereas in both of the other regions they constitute about $50 \%$ of students. The same situation can be observed in natural sciences. In Baden-Württemberg, the proportion of women in information engineering is very low, as well as in physics and chemistry. In Rhône-Alpes, more than half of the students are female in all of the subjects except for information engineering. In Catalonia, the spread of the distribution of women is the largest: there are only $15 \%$ in information engineering and $84 \%$ in biology. These patterns of differences between regions cannot be found in the subject of engineering. It is very strongly dominated by men in all three regions. Again, differences between the regions can be identified. In Catalonia, $21 \%$ of students in engineering are women, whereas in Rhône-Alpes only $9 \%$ of those students are female. 
Hence, a similarity can be recognised between the three regions and the percentage of women in the different subjects. There are «female subjects» like humanities, languages and social sciences, and there are "male subjects» like information engineering and physics/chemistry. The percentages are quite similar in both Rhône-Alpes and Catalonia. On a lower level the same effects can be recognised in Baden-Württemberg.

\subsection{Motivations for the choice of subject}

The choice of subject is influenced by the different expectations students have towards their subjects. Across all subjects women are on average more likely to choose their subject because of interest in the subject and idealistic reasons (intrinsic motivations), while men more often emphasise material motivations and the possibility to achieve a high social status (extrinsic motivations) (cf. Bradley, 2000: 11; Bargel et al, 1984).

Yet, considering the different motivations in specific subjects, one can see that men who are studying female subjects such as humanities, languages and social sciences also give idealistic reasons. And women who are studying male subjects such as economics and engineering are also motivated by materialistic reasons (cf. Grimmer, 2004). This result seems to affirm the thesis that "differences between students of different disciplines [..] [are; B.G., T.R.] greater than differences between the sexes» (Thomas, 1990: 26).

This fact could be one possible explanation for the different distribution of gender and subject: in general, women seem to have other intentions than men - and because of that they choose subjects they believe to be appropriate to realise their aims in the best way. (For an overview on how students perceive feminine and masculine disciplines see Thomas, 1990: 36f.)

\subsection{Women's study situation: contacts, integration, difficulties and stress}

There seem to be no differences in the integration of women as opposed to that of men at university. All students are satisfied with the relations between students and teaching staff - there are no differences in terms of gender and regions. Furthermore, Catalonian women are even slightly more satisfied with their contacts than the other groups (cf. Bargel, Hadji and Masjuan, 2003: 103-108).

In spite of that, during their studies women seem to have more difficulties and stress than men (see table 2). They experience more pressure in coping with exams than their male colleagues and have more problems with the social climate (measured by competition between students and difficulties with contacts to teaching staff). Furthermore, they are more likely to have anxieties about failing their studies and they are more anxious about future exams. These results seem to confirm the thesis that women feel less comfortable at universities than men (cf. Krüger, 1986: 251). The findings of the German student survey lead to the same conclusion (for a more detailed discussion see Sandberger, 1992: 16ff). 
Table 2. Difficulties and stress with exams, contacts and study success (Percentages, categories $5+6$; scale $0-6$ )

\begin{tabular}{|c|c|c|c|c|c|c|}
\hline & $\begin{array}{l}\text { Baden } \\
\text { male }\end{array}$ & $\begin{array}{l}\text { Württemberg } \\
\text { female }\end{array}$ & $\begin{array}{l}\text { Rhôn } \\
\text { male }\end{array}$ & $\begin{array}{l}\text {-Alpes } \\
\text { female }\end{array}$ & $\begin{array}{l}\text { Catal } \\
\text { male }\end{array}$ & $\begin{array}{l}\text { nia } \\
\text { female }\end{array}$ \\
\hline \multicolumn{7}{|l|}{ Stress with exams } \\
\hline $\begin{array}{l}\text { I am anxious about exams } \\
\text { most of the time }\end{array}$ & 16 & 39 & 37 & 57 & 31 & 46 \\
\hline $\begin{array}{l}\text { During exams I am often very } \\
\text { excited and nervous }\end{array}$ & 13 & 23 & 24 & 28 & 13 & 23 \\
\hline $\begin{array}{l}\text { Difficulties to prepare exams } \\
\text { efficiently }\end{array}$ & 55 & 53 & 66 & 73 & 69 & 75 \\
\hline \multicolumn{7}{|l|}{ Difficulties with contacts } \\
\hline $\begin{array}{l}\text { Difficulties with competition } \\
\text { between the students }\end{array}$ & 14 & 21 & 19 & 28 & 23 & 31 \\
\hline $\begin{array}{l}\text { Difficulties with contacts to the } \\
\text { teaching staff }\end{array}$ & 29 & 29 & 38 & 45 & 46 & 48 \\
\hline
\end{tabular}

\section{Stress with study success} and future exams

I am often worried whether

I will manage my studies

Stress caused by future exams

31

41

24

39

26

Source: FREREF Student Survey 2000-2002, Barcelona/Grenoble/Konstanz.

\subsection{Intentions to do a doctorate}

At first glance, in each of the regions women and men do not differ significantly in their intentions to do a $\mathrm{PhD}$ (see chart 1). One can rather find differences between the observed regions: in Baden-Württemberg, the percentage of students having those intentions is the highest, whereas in Rhône-Alpes it is the lowest.

If we take a closer look at the figures and distinguish between subjects, a more complex relationship is revealed (see table 3 ). Baden-Württembergian men intend to earn a doctorate after graduation more often than women do in all of the subjects. In some disciplines, like law and social sciences, men are twice as likely to state that they intend to do a PhD, while in others they are only slightly above the level of women. In Rhône-Alpes and Catalonia, there are some subjects like law in which women exceed men in their intention to do a PhD, and others like engineering in which women are less likely to express such an intention ${ }^{2}$.

2. A chi ${ }^{2}$ test was conducted for each subject separately to figure out if this relationship between gender and the intention to do a PhD (v173) is significant. Unfortunately the number of cells with expected frequencies of $<5$ was too large $(>20 \%)$. Still, we believe that there is a significant relationship between those variables, if we take subjects into account. 

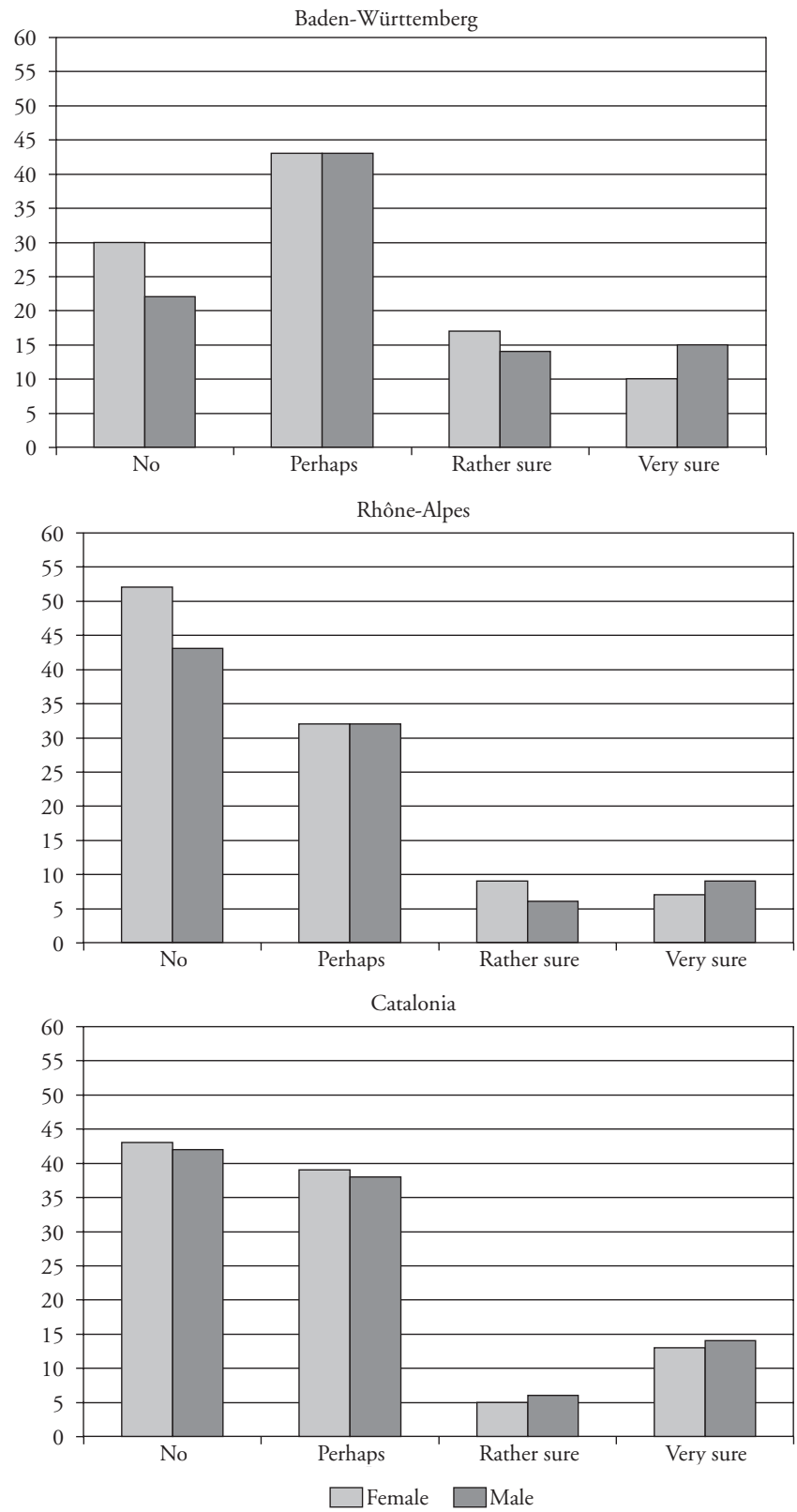

Chart 1. Intention of female and male students to do $<\mathrm{PhD}$ (a doctoral thesis) at universities in the three regions (Percentages).

Source: FREREF Student Survey 2000-2002, Barcelona/Grenoble/Konstanz. 
Table 3. Intention to do a PhD by gender and subject (per cent; collapsed categories "probably» and "certainly»)

\begin{tabular}{|c|c|c|c|c|c|c|}
\hline & \multicolumn{2}{|c|}{$\begin{array}{l}\text { Baden-Württemberg } \\
\text { (973) }\end{array}$} & \multicolumn{2}{|c|}{$\begin{array}{l}\text { Rhône-Alpes } \\
(1,208)\end{array}$} & \multicolumn{2}{|c|}{$\begin{array}{l}\text { Catalonia } \\
(1,775)\end{array}$} \\
\hline & m & f & m & $\mathrm{f}$ & m & $\mathrm{f}$ \\
\hline Humanities & 17.3 & 15.4 & 5.6 & 11.2 & 38.1 & 21.4 \\
\hline Social sciences & 31.3 & 18.2 & 25.8 & 8.2 & 20.4 & 17.7 \\
\hline Law & 51.8 & 28.0 & 2.8 & 9.1 & 4.0 & 15.4 \\
\hline Economics & 11.7 & 5.4 & 15.9 & 5.1 & 11.1 & 13.8 \\
\hline Medicine & 88.3 & 68.8 & 80.0 & 95.8 & 23.7 & 20.5 \\
\hline Natural sciences & 36.9 & 32.9 & 17.2 & 15.1 & 26.7 & 16.0 \\
\hline Engineering & 15.2 & 9.5 & 6.8 & 0.0 & 22.5 & 10.3 \\
\hline Others & 16.1 & 6.4 & - & - & - & - \\
\hline Total & 29.1 & 26.8 & 14.5 & 15.8 & 20.2 & 17.4 \\
\hline
\end{tabular}

Source: FREREF Student Survey 2000-2002, Barcelona/Grenoble/Konstanz.

If we compare those results with the official statistics on first degree and $\mathrm{PhD}$ graduates, we get a paradoxical result. Despite the fact that about half $(45 \%)$ of the German graduates in 2000 were women, they constituted only about a third (33.4\%) of PhD graduates (cf. European Commission, 2002: 101ff). In France, 56.5\% of graduates in 1999 were female, while their number among $\mathrm{PhD}$ graduates was $41.1 \%$. A similar situation can be found in Spain, where a large number $(59.7 \%)$ of graduates was female in 1999 . Yet, women only made up $43.8 \%$ of graduate students with a $\mathrm{PhD}$.

How can this decrease in numbers of women on the higher levels of the academic ladder be explained? Moreover, how can it be explained, if we take into account that overall women and men do not seem to differ in their intentions to earn a doctorate? These are the two questions we will try to answer in the next chapter.

\section{Gender, interest in science and research, and the intention to do a doctorate}

In recent years there has been a rising awareness among policy makers for the low proportion of women among PhD students. A number of reports has been published to explore this topic on a European level and the European Commission has founded the so-called Helsinki Group and the ETAN group to advise policy makers on how to increase equality in science (e. g. European Commission, 2000, 2002). The pattern of gender inequality in science is similar in all the European countries. The further up one looks at the academic ladder, the less women and the more men one finds. For women a career in 
science can be compared to a «leaky pipeline» or an «obstacle course» (Epstein, 1991). How can this decreasing number of women on higher levels of the academic career be explained?

\subsection{Theory and hypotheses}

In the literature on the role of gender in higher education and science we can find two broad explanations for the relatively small number of women pursuing a career in science (cf. Krais, 2000a: 17ff). While some research focuses on the women themselves, other social scientists look for explanations in the role science and university play. The latter approach can be described as structural and tries to reveal the specific barriers and discriminations inherent to the scientific community (e. g. Krais, 2000b; Geenen, 2000; Bielby, 1991). Thus, the structures and mechanisms of science itself are the objects of research in structural approaches. Others look for explanations in the women and their characteristics themselves and can be described as individualistic. Among them we can distinguish between those that emphasise that the life patterns of women are different from those of men (e. g. Bauer, 1993) and those that focus on the attitudes and beliefs of women (e. g. Beck-Gernsheim, 1980).

The questionnaire of the FREREF student surveys allows us to test hypotheses of those individualistic approaches that focus on the attitudes and beliefs of women. The rules, structures and mechanisms of science and university can hardly be grasped in it. Therefore, we will try to examine carefully whether an individualistic approach can explain the discrepancy between the intention of women to do a PhD and the actual number of women doing a PhD.

In the early 1980s, Dippelhofer-Stiem conducted research on different study styles in German higher education (Dippelhofer-Stiem, 1986). The results of this panel study of students in different subjects lead her to the conclusion that women are less likely to study in a way that is characterised by a critical interest in science and the subject beyond the curriculum. Furthermore, she found out that female students emphasised the importance of science and research in their lives less often than their male counterparts in the same subjects did. According to role theory, this would mean that women acquire a different attitude towards science and research during their socialisation (cf. BeckGernsheim, 1980). These attitudes are rooted in a more general system of gender differences that are the result of different expectations of parents and other adults towards children according to their gender. Such expectations relate to the way a girl/boy should behave, dress, move, and talk, what her/his interests are and what frightens her/him etc. (cf. Beck-Gernsheim, 1980: 14).

Could this proposed lower interest of women in science explain why they are less likely to earn a doctorate? To answer this question we will have to test two hypotheses:

1) Do men and women differ in their interest in research and science?

2) Does this interest influence the intention to do a doctoral thesis? 
Our first hypothesis tests if the assumption of previous research holds true for our variables and our samples. The second hypothesis should give us a hint whether the interest in science and research has any effect at all on the decision to do a PhD. Unfortunately, we cannot observe the actual decision and realisation of that intention. Nevertheless, we think that, if there is a relationship between this interest and the intention, we can assume that a lack of interest will decrease the probability of actually doing a PhD.

However, we have to keep in mind that university is not a homogenous universe. Different subjects constitute different subject cultures of which students are part of (cf. Multrus 2004; Krais, 1996). These subject cultures relate (amongst other things) to the attitudes students have towards science and research. Thus, in our analysis of differences between men and women we have to consider the differences due to subjects as well. Otherwise we would get significant differences between female and male students when these are indeed effects of the subject culture.

Hence, we decided to focus on subjects which can be easily allocated to one of the "two cultures" (Snow, 1964), i.e. arts and humanities on the one hand and science on the other. We expect those two groups to differ significantly in the importance of science and research and thus also in the role a $\mathrm{PhD}$ degree plays. Moreover, those subjects vary significantly in terms of the proportion of men and women (see table 1) and are associated with «masculine» (science) and «feminine» (humanities) qualities (cf. Thomas, 1990: 36f).

\subsection{Measurement}

The subjects we allocated to the humanities group were all the humanities, languages and social sciences (except for economics and business studies). The science group consists of all natural sciences and all engineering subjects. One of the reasons for our decision to collapse different subjects into these two groups or cultures was also a practical consideration. For a sophisticated analysis of our variables we have to ensure that the subgroups according to subject and gender are sufficiently large. Therefore we had to collapse engineering and the natural sciences into one group, even though some might argue that these constitute different subject cultures. Yet, students of those two subject groups differ only slightly in terms of their interest in science and research (cf. Bargel, Hadji and Masjuan, 2003: 24). Furthermore, some social scientists argue that both belong to the "hard» sciences and are opposed to the «soft» humanities (cf. Becher, 1987). Thus, for our purposes it seemed plausible and legitimate to collapse those two disciplines into one larger subject group with a common culture.

Three variables were chosen to measure the interest in science and research:

v331: importance of working scientifically in a job.

v337: importance of the opportunity to carry out research in new areas in a job. v401: importance of science and research in one's life. 
These variables are semantic differential scales with 7 levels ranging from «not important» (0) to "very important» (6). By computing the mean score on these three items for each respondent we could build a scale that should measure the interest in science and research. Taking into account the small number of items the scale can be considered reliable (Cronbach's alpha 0.677). A factor analysis was conducted to test for unidimensionality and yielded a factor solution with only one factor. Hence, we can also assume the scale to be unidimensional.

In order to test our first hypothesis, a two-way ANOVA has to be conducted. This allows us to estimate the effects of the independent variables gender and subject (both nominal) on our dependent «interest in science and research» scale (interval level). An advantage of ANOVA is that it detects interaction effects between dependent variables and thus enables sophisticated analyses of the effects of the dependent variables. Since our total $n$ in each of the regions is quite large (B-W: 984, R-A: 1,230, CAT: 1,823), we do not have to compute tests for normality and homogeneity of variances (cf. Box, 1954).

The second hypothesis can be tested by calculating a correlation coefficient between the independent variable «interest in science and research" (interval level) and the dependent variable «intention to do a $\mathrm{PhD}$ » (ordinal level). The appropriate coefficient here is Spearman's rho, which is suitable to calculate correlations between ordinal level variables. Furthermore, Spearman's rho allows us to estimate the strength of relationship between variables. According to previous considerations we have to calculate Spearman's rho for each subgroup constituted by the various combinations of gender and subject groups.

Table 4. «Interest in science and research» by gender and subject (arithmetic means and standard deviations)

\begin{tabular}{|c|c|c|c|c|c|c|}
\hline & \multicolumn{2}{|c|}{ Baden-Württemberg } & \multicolumn{2}{|c|}{ Rhône-Alpes } & \multicolumn{2}{|l|}{ Catalonia } \\
\hline & $\mathrm{m}$ & $\mathrm{f}$ & $\mathrm{m}$ & $\mathrm{f}$ & $\mathrm{m}$ & $\mathrm{f}$ \\
\hline Humanities & $\begin{array}{l}M=3.652 \\
S D=1.324 \\
(68)\end{array}$ & $\begin{array}{l}M=3.408 \\
S D=1.421 \\
(138)\end{array}$ & $\begin{array}{l}M=3.358 \\
S D=1.197 \\
(67)\end{array}$ & $\begin{array}{l}M=3.186 \\
S D=1.250 \\
(369)\end{array}$ & $\begin{array}{l}M=3.938 \\
S D=1.189 \\
(143)\end{array}$ & $\begin{array}{l}M=3.723 \\
S D=1.145 \\
(442)\end{array}$ \\
\hline Science & $\begin{array}{l}M=3.957 \\
S D=1.342 \\
(297)\end{array}$ & $\begin{array}{l}M=4.068 \\
S D=1.442 \\
(110)\end{array}$ & $\begin{array}{l}M=4.097 \\
S D=1.161 \\
(267)\end{array}$ & $\begin{array}{l}M=4.149 \\
S D=1.177 \\
(168)\end{array}$ & $\begin{array}{l}M=4.474 \\
S D=1.053 \\
(344)\end{array}$ & $\begin{array}{l}M=4.757 \\
S D=0.952 \\
(252)\end{array}$ \\
\hline $\begin{array}{l}\text { Both subject } \\
\text { groups }\end{array}$ & $\begin{array}{l}M=3.901 \\
S D=1.342 \\
(365)\end{array}$ & $\begin{array}{l}M=3.701 \\
S D=1.464 \\
(248)\end{array}$ & $\begin{array}{l}M=3.949 \\
S D=1.204 \\
(334)\end{array}$ & $\begin{array}{l}M=3.487 \\
S D=1.306 \\
(537)\end{array}$ & $\begin{array}{l}M=4.317 \\
S D=1.120 \\
(487)\end{array}$ & $\begin{array}{l}M=4.098 \\
S D=1.188 \\
(694)\end{array}$ \\
\hline Total & & $\begin{array}{l}3.820 \\
=1.395 \\
\end{array}$ & & $\begin{array}{l}664 \\
.287\end{array}$ & $\begin{array}{l}\text { M } 4 \\
\text { SD } \\
(1.1\end{array}$ & $\begin{array}{l}188 \\
165 \\
1)\end{array}$ \\
\hline
\end{tabular}

Source: FREREF Student Survey 2000-2002, Barcelona/Grenoble/Konstanz. 
Table 5. The influence of gender and subject on «interest in science and research» (two-way ANOVA)

\section{Baden-Württemberg}

\begin{tabular}{lrrrrrl} 
Source & $\begin{array}{l}\text { Type III } \\
\text { Sum of Squares }\end{array}$ & \multicolumn{1}{c}{ df } & Mean Square & \multicolumn{1}{c}{ F } & \multicolumn{1}{l}{ Sig. } & $\begin{array}{l}\text { Eta } \\
\text { Squared }\end{array}$ \\
\hline Corrected Model & $37.699^{a}$ & 3 & 12.566 & 6.636 & 0.000 & 0.032 \\
Intercept & 6613.700 & 1 & 6613.700 & 3492.367 & 0.000 & 0.852 \\
subject & 27.083 & 1 & 27.083 & 14.301 & 0.000 & 0.023 \\
gender & 0.513 & 1 & 0.513 & 0.271 & 0.603 & 0.000 \\
subject ${ }^{*}$ gender & 3.654 & 1 & 3.654 & 1.929 & 0.165 & 0.003 \\
Error & 1153.299 & 609 & 1.894 & & & \\
Total & 10134.917 & 613 & & & & \\
Corrected Total & 1190.998 & 612 & & & & \\
\hline
\end{tabular}

a. $\mathrm{R}$ squared $=0.032$ (Adjusted R squared $=0.027$ ).

\section{Rhône-Alpes}

\begin{tabular}{lcrrrrl} 
Source & $\begin{array}{l}\text { Type III } \\
\text { Sum of Squares }\end{array}$ & \multicolumn{1}{c}{ df } & Mean Square & \multicolumn{1}{c}{ F } & \multicolumn{1}{l}{ Sig. } & $\begin{array}{l}\text { Eta } \\
\text { Squared }\end{array}$ \\
\hline Corrected Model & $180.338^{\mathrm{b}}$ & 3 & 60.113 & 41.363 & 0.000 & 0.125 \\
Intercept & 8002.938 & 1 & 8002.938 & 5506.704 & 0.000 & 0.864 \\
subject & 106.024 & 1 & 106.024 & 72.954 & 0.000 & 0.078 \\
gender & 0.537 & 1 & 0.537 & 0.369 & 0.543 & 0.000 \\
subject ${ }^{*}$ gender & 1.836 & 1 & 1.836 & 1.263 & 0.261 & 0.001 \\
Error & 1260.018 & 867 & 1.453 & & & \\
Total & 13134.583 & 871 & & & & \\
Corrected Total & 1440.356 & 870 & & & &
\end{tabular}

b. R squared $=0.125$ (Adjusted R squared $=0.122$ ).

\section{Catalonia}

\begin{tabular}{|c|c|c|c|c|c|c|}
\hline Source & $\begin{array}{l}\text { Type III } \\
\text { Sum of Squares }\end{array}$ & $\mathrm{df}$ & Mean Square & $\mathrm{F}$ & Sig. & $\begin{array}{l}\text { Eta } \\
\text { Squared }\end{array}$ \\
\hline Corrected Model & $214.232^{\mathrm{c}}$ & 3 & 71.411 & 60.623 & 0.000 & 0.134 \\
\hline Intercept & 17689.281 & 1 & 17689.281 & 15017.165 & 0.000 & 0.927 \\
\hline subject & 152.780 & 1 & 152.780 & 129.701 & 0.000 & 0.099 \\
\hline gender & 0.278 & 1 & 0.278 & 0.236 & 0.627 & 0.000 \\
\hline subject* ${ }^{*}$ gender & 15.354 & 1 & 15.354 & 13.035 & 0.000 & 0.011 \\
\hline Error & 1386.432 & 1177 & 1.178 & & & \\
\hline Total & 22318.583 & 1181 & & & & \\
\hline Corrected Total & 1600.664 & 1180 & & & & \\
\hline
\end{tabular}

${ }^{c}$. $\mathrm{R}$ squared $=0.134$ (Adjusted R squared $=0.132$ ).

Source: FREREF Student Survey 2000-2002, Barcelona/Grenoble/Konstanz. 


\subsection{Results}

A look at the means of «interest in science and research» suggests several things (see table 4). Since the scale ranges from 0 to 6 , the overall means in all regions are quite high (B-W: 3.820; R-A: 3.664; CAT: 4.188). If we compare men and women without taking their subject group into account, we would tend to accept our first hypothesis. Men seem to be slightly more interested in science and research than women. Yet, a closer look, which includes subject groups, reveals a more complex relationship. While female students in humanities have on the average lower scores on the interest scale than males, they exceed men in the science group. This holds true for each region. Finally, the relationship between subject group and 'interest in science and research' seems to be much stronger than the effect of gender on the interest.

The two-way ANOVA confirms this observation (see table 5). While there is no significant main effect of gender on the «interest in science and research" in all of the regions, there is a significant main effect of the subject group with effect sizes of moderate strength. Furthermore, there is a significant interaction effect in Catalonia, however the effect size is rather small.

An analysis of the relationship between «interest in science and research» and the «intention to do a $\mathrm{PhD}$ » shows that there is a significant relationship between those two variables in each of the regions (see table 6). The strength of this relationship can be described as moderate to substantial. This association stays significant when we consider gender and subject in our calculations and is therefore very robust.

What do these results imply for our hypotheses? Our first hypothesis has to be rejected. Female and male students do not differ in terms of their interest in science and research. Observed differences between men and women are differences between subjects. The subject culture of the natural sciences and of engineering emphasises research and science and thus science and engi-

Table 6. Relationship between «interest in science and research» and the «intention to do a PhD» (v173) (Correlation coefficient Spearman's rho)

\begin{tabular}{|c|c|c|c|c|c|c|}
\hline & \multicolumn{2}{|c|}{ Baden-Württemberg } & \multicolumn{2}{|c|}{ Rhône-Alpes } & \multicolumn{2}{|c|}{ Catalonia } \\
\hline & $\mathrm{m}$ & $\mathrm{f}$ & $\mathrm{m}$ & $f$ & $\mathrm{~m}$ & $\mathrm{f}$ \\
\hline Humanities & $\begin{array}{l}0.400^{* *} \\
(59)\end{array}$ & $\begin{array}{l}0.538^{* *} \\
(114)\end{array}$ & $\begin{array}{l}0.377^{* *} \\
(58)\end{array}$ & $\begin{array}{l}0.436^{* *} \\
(329)\end{array}$ & $\begin{array}{l}0.312^{* *} \\
(127)\end{array}$ & $\begin{array}{l}0.292^{* *} \\
(385)\end{array}$ \\
\hline Science & $\begin{array}{l}0.544^{* *} \\
(266)\end{array}$ & $\begin{array}{l}0.659^{* *} \\
(94)\end{array}$ & $\begin{array}{l}0.415^{* *} \\
(244)\end{array}$ & $\begin{array}{l}0.390^{* *} \\
(155)\end{array}$ & $\begin{array}{l}0.350^{* *} \\
(314)\end{array}$ & $\begin{array}{l}0.348^{* *} \\
(215)\end{array}$ \\
\hline $\begin{array}{l}\text { Both subject } \\
\text { groups }\end{array}$ & $\begin{array}{l}0.522^{* *} \\
(325)\end{array}$ & $\begin{array}{l}0.616^{* *} \\
(208)\end{array}$ & $\begin{array}{l}0.392^{* *} \\
(302)\end{array}$ & $\begin{array}{l}0.408^{* *} \\
(484)\end{array}$ & $\begin{array}{l}0.320^{* *} \\
(441)\end{array}$ & $\begin{array}{l}0.241^{* *} \\
(600)\end{array}$ \\
\hline Total & \multicolumn{2}{|c|}{$\begin{array}{l}0.559^{* *} \\
(533)\end{array}$} & \multicolumn{2}{|c|}{$\begin{array}{l}0.415^{* *} \\
(790)\end{array}$} & \multicolumn{2}{|c|}{$\begin{array}{l}0.276^{* *} \\
(1.051)\end{array}$} \\
\hline
\end{tabular}

**. significant at the 0.01 level (two-tailed).

Source: FREREF Student Survey 2000-2002, Barcelona/Grenoble/Konstanz. 
neering students, no matter if they are male or female, are more interested in them than those in the humanities group.

The second hypothesis is accepted. Scientific interest has a substantial influence on a student's intention to do a $\mathrm{PhD}$. As we stated above, we can also assume that this scientific interest has a positive influence on the actual realisation of that intention. However, men and women are equally interested in science and research. The decrease in numbers of women among PhD students can therefore hardly be explained by a lack of interest in science and research.

\section{Conclusion and Outlook}

Male and female students are different in many aspects. They choose different subjects and have different motivations for their choice. While women constitute the majority in the humanities and the social sciences, they are the minority in subjects like engineering, physics and information engineering. Their motivations in choosing a specific subject are often intrinsic and not extrinsic like those of male students. However, in subjects, which are not typically female subjects like economics, they also give extrinsic motivations and do not differ significantly from their male counterparts in this regard. Hence, subject can be more important than gender in explaining differences between students. Another difference between male and female students is that women often feel less comfortable than men at university. Although they are overall as eager as men to earn a doctorate, there are subjects in which men exceed women in their intention to do a PhD and others (at least in Rhône-Alpes and Catalonia) in which female students intend to earn a doctorate more often than men.

To answer the question why the percentage of female $\mathrm{PhD}$ students is relatively small when compared to that of female undergraduates, we looked for an explanation in a proposed lack of interest in science and research. However, our analysis could reject the hypothesis that women are less interested than $m^{3}{ }^{3}$. Observed differences were mainly due to subject and not to gender. Yet, this interest influences the intention to do a $\mathrm{PhD}$ and we assume that it is also important for a realisation of that intention.

Engler (1993: 68) identifies two reasons for differences between male and female students. There are differences which are a result of one's gender and others which are due to a socialisation in one's subject culture. Those differences are thus (more or less) common to all students of that subject, regardless of gender. The interest of science and research seems to be a difference of the latter type. Yet, we believe that to some extent differences between men and women in higher education constitute themselves before students enrol at university. The choice of subject is a decision which is heavily influenced

3. Geenen could show that many lecturers (especially in female subjects) wrongly assume that men are more interested in their subject than female students (Geenen, 2000: 102f). 
by one's gender. Women choose subjects because they seem suitable to realise their aims in the best way. Since women are more likely to have intrinsic motivations (see 3.2), they choose subjects which promise to have these qualities (e. g. pedagogy). Thus, the interest in science and research is certainly part of the subject culture. This culture in turn is also constituted by students and is also structured by gender (cf. Thomas, 1990).

Since male and female students do not differ in their interest in science and research, what else could then explain the «leaky pipeline» of the academic career? One possible explanation could be that, as we saw above, women feel less comfortable at university (see 3.3). This lack of confidence could keep women from actually taking the final step and realise the intention to do a $\mathrm{PhD}$, despite a great interest in science and research. Another reason could be that science and university itself are male institutions in which women face specific problems and have to cross barriers, which do not exist for men. The structural approach of Krais (2000b) suggests exactly this. She describes science as a field in the Bourdieuan sense. Science is a "game», a "contest» for recognition in the scientific community. In this contest only men are regarded as proper adversaries, while women are excluded from it. Perhaps women are more and more aware of this misrecognition as their graduation nears the completion and decide not to earn a doctorate, even though they once had the intention to give it a try.

\section{Appendix}

Questions used in our inferential analysis

Which of the following elements are important in a job?

- To work scientifically (v331)

- The opportunity to carry out research in new areas (v337)

not important $\begin{array}{lllllllll}0 & 1 & 2 & 3 & 4 & 5 & 6 & \text { very important }\end{array}$

Please state how important the following spheres of life are for you:

- Science and research (v401)

not important $\quad \begin{array}{llllllll}0 & 1 & 2 & 3 & 4 & 5 & 6 & \text { very important }\end{array}$

Do you plan to...

— Do a PhD? (v173)

no perhaps probably certainly I do not know yet 


\section{References}

BARgEL, Tino et al. (1984). Studiensituation und studentische Orientierungen. Eine empirische Untersuchung im Wintersemester 1982/83. (BMBW: Bildung und Wissenschaft, vol. 5). Bad Honnef.

Bargel, Tino; HadjI, Charles; Masjuan, Josep (eds.) (2003). Almanach de Données par régions, sexe et filières. Konstanz/Grenoble/Lyon/Barcelona.

BAUER, Annemarie et al. (1993). Die Regel der Ausnahme: Hochschulfrauen. Eine empirische Untersuchung über Lebensumstände von Wissenschaftlerinnen an den Universitäten des Landes Baden-Württemberg. Frankfurt a.M./Berlin/Bern: Lang.

Becher, Tony (1987). Disciplinary Discourse. Studies in Higher Education 12.3, p. 261-274.

BeCK-GernsheIm, Elisabeth (1980). Das halbierte Leben. Männerwelt Beruf, Frauenwelt Familie. Frankfurt a.M.: Fischer.

BIELBY, William (1991). «Sex Differences in Careers: Is Science a Special Case?». In Zuckerman, Harriet; Cole, Jonathan; Breuer, John (eds.). The Outer Circle. Women in the Scientific Community. New York/London: Norton, p. 171-187. Bourdieu, Pierre (1998). La Domination Masculine. Paris: Seuil.

Box, George (1954). Some Theorems on quadratic forms applied in the study of analysis of variance problems, Vol. 2: Effects of inequality of variance and of correlation between errors in the two-way classification. Annals of Math. Statistics 25, p. 416-480.

BRADLEY, Karen (2000). «The Incorporation of Women into Higher Education: Paradoxical Outcomes? ». Sociology of Education 73.1, p. 1-18.

DiPPELHOFER-STIEM, Barbara (1986). «Ist forschendes Lernen Männersache? Empirische Hinweise auf Entwicklung und Determinanten eines studentischen Lernstils». In Clemens, Bärbel et al. (eds.). Töchter der Alma Mater. Frauen in der Berufs-und Hochschulforschung. Frankfurt a.M./New York: Campus, p. 235-249.

EnGLER, Steffani (1993). Fachkultur, Geschlecht und soziale Reproduktion. Eine Untersuchung über Studentinnen und Studenten der Erziehungswissenschaft, Rechtswissenschaft, Elektrotechnik und des Maschinenbaus. Weinheim: Deutscher Studienverlag.

EPSTEIN, Cynthia Fuchs (1991). «Constraints on Excellence: Structural and Cultural Barriers to the Recognition and Demonstration of Achievement». In ZUCKERMAN, Harriet et al. (eds.). The Outer Circle. Women in the Scientific Community. New York/London: Norton, p. 239-258.

European Commission (2000). Science Policies in the European Union. Promoting Excellence through Mainstreaming Gender Equality. A Report from the ETAN expert working group on Women and Science. ftp://ftp.cordis.lu/publimproving/ docs/g_wo_etan_en_200101.pdf.

- (2002). National Policies on Women and Science in Europe. A Report about Women and Science in 30 countries. By Teresa Rees. ftp://ftp.cordis.lu/pub/ improving/ docs/women_national_policies_full_report.pdf.

GEENEN, Elke (2000). «Akademische Karrieren von Frauen an wissenschaftlichen Hochschulen». In KRAIS, Beate (ed.). Wissenschaftskultur und Geschlechterordnung. Über die verborgenen Mechanismen männlicher Dominanz in der akademischen Welt. Frankfurt a.M./New York: Campus, p. 83-105.

GrIMMER, Bettina (2004). «Effects of Gender at Universities in the three regions of Baden-Württemberg, Catalonia, and Rhône-Alpes». In BARGEL, Tino (ed.). 
Heterogeneity and Inequality of Students: An International Comparison. Contributions to a Conference of FREREF at the Villa Vigoni. (Hefte zur Bildungs und Hochschulforschung, vol. 42.) Konstanz.

KRAIS, Beate (1996). «The Academic Disciplines: Social Field and Culture». Comparative Social Research 2, p. 93-111.

- (2000a). «Einleitung: Die Wissenschaft und die Frauen». In KRAIS, Beate (ed.). Wissenschaftskultur und Geschlechterordnung. Über die verborgenen Mechanismen männlicher Dominanz in der akademischen Welt. Frankfurt a.M./New York: Campus, p. 9-29.

- (2000b). «Das soziale Feld Wissenschaft und die Geschlechterverhältnisse. Theoretische Sondierungen». In KraIS, Beate (ed.). Wissenschaftskultur und Geschlechterordnung. Über die verborgenen Mechanismen männlicher Dominanz in der akademischen Welt. Frankfurt a.M./New York: Campus, p. 31-54.

KRÜGER, Heidemarie (1986). «Frauen im Studium: Studieren mit dem weiblichen Arbeitsvermögen». In ClEMENS, Bärbel et al. (eds.). Töchter der Alma Mater. Frauen in Berufs- und Hochschulforschung. Frankfurt a.M./New York: Campus, p. 251-270. MulTrus, Frank (2004). Fachkulturen. Begriffsbestimmung, Herleitung und Analysen. Eine empirische Untersuchung über Studierende deutscher Hochschulen. Doctoral Thesis at the University of Konstanz.

PEISERT, Hansgert (1967). Soziale Lage und Bildungschancen in Deutschland. München: Piper.

SANDBERGER, Johann-Ulrich (1992). Studentinnen. Studienerfahrungen, Zukunftsperspektiven, Forderungen. (Hefte zur Bildungs und Hochschulforschung, vol. 8). Konstanz.

Snow, Charles (1964). The Two Cultures. Cambridge: Cambridge University Press. ThOMAS, Kim (1990). Gender and Subject in Higher Education. Buckingham: Open University Press. 